DOI https://doi.org/10.18551/rjoas.2017-11.48

\title{
TRMM 3B43 RAIN DATA INFORMATION IN DETERMINING LONG WET AND DRY PERIODS IN FARMING BUSINESS IN MOONSON AREA
}

\author{
Rusmayadi Gusti* \\ Faculty of Agriculture, Banjarbaru Lambung Mangkurat University, Indonesia
}

Noor Riza Arian

Syamsuddin Noor Banjarbaru Airport Meteorological, Climatology, and Geophysical Agency, Indonesia

\author{
Ruslan Muhammad \\ Facult of Forestry, Banjarbaru Lambung Mangkurat University, Indonesia
}

E-mail: gustirusmayadi@gmail.com

\begin{abstract}
Based on the observation towards climate station in several agriculture production centers, there is an increase temperature. Temperature rise due to greenhouse effect is very clearly visible, e.g., in Banjarbaru Indonesian Agency of Meteorological, Climatology, and Geophysics (BMKG), misal di stasiun BMKG Banjarbaru, Banjarmasin Sei Tabuk Special Farm Meteorology Station (SMPK), and South Kalimantan Kotabaru BMKG. This temperature rise impacted to plant's respiration increase that led to the reduction of photosynthesis result. Adaptation strategy with plants water balance analysis to determine the correct planting time and surplus period and water deficit, in various growth phases, is one of water permanent strategic measures to know water suffiency in the field. Material used in this research is TRMM from 3B43 type in the form of grid with monthly temporal resolution and spatial resolution $0.25^{\circ} \times 0.25^{\circ}$ with data from $1998-2015$ period. Data format in the form of binary from ftp://disc2.nascom.nasa.gov/data/TRMM/Gridded/3B43_V7. Reanalysis surface temperature data is grid data from European Centre for Medium-Range Weather Forecasts (ECMWF) from 1998 -2015 period in netcdf format. Water balance analysis used Thornthwaite and Mather (1957) method. Water balance analysis shown groundwater in sufficient category $(>60 \%)$ happens during November - July period, meanwhile water surplus happens during December - June period. Whereas during August - October period is in less period $(<40 \%)$. This information can be used in the formulation of one season planting pattern both in wet or dry field.
\end{abstract}

\section{KEY WORDS}

TRMM, water balance analysis, surplus, deficit, rainy season, dry season.

Since 1980s, it is predicted that the global warming has become reality, like what happened to several research results related directly with global and local climate change or climate aberrations. Based on the observation towards severa climate stations in several agriculture centers, it shows that there is temperature rise. Temperature rise due to greenhouse effect is very clearly visible, e.g., in Banjarbaru BMKG, Banjarmasin Sei Tabuk SMPK, and South Kalimantan Kotabaru BMKG. This temperature rise resulted in the increase of plant's respiration that led to photosynthesis result reduction.

Yonny et al. (1999) who stated that the most important impact of climate change is not in gradual warming but instead in the occurance of extreme, e.g., long drought, thunder storm, flood, or landslide with rising frequency and magnitude. The meteorology researchers in CNRM believe that the rising rainfall quantity is the impact of temperature rise that will trigger water loss in the form of evaporation.

Anticipative measure towards climate change and its impact, analysis towards climate parameter in various observation scales must be improved, especially the one related with 
the ability of weather forecast. The ability upgrade for accourate weather forecast can be conducted up to the poured water volume and avalaibility and storing in ground for certain length of countable time. Therefore correct planting time can be predicted to anticipate extreme climate change, and able to give information or early warning to farmer communities on drought and flood. If rain characteristics or rainfall in certain place in the future is unknown, then the conducted analysis can only be rain evaluation.

Technology development in remote sensing, e.g., satellite and radar, rainfall measuring conducted by that technology until enabling it for rainfall observation in large areas even area that unreachable by conventional equipment. The advantages of remote sensing should be utilized further to learn weather and climate in an area for the interest of water resource management and it's utilization for society welfare (Syaifullah, 2014). Especially for tropical area, at the moment there is remote sensing equipment that able to conduct rainfall measurement mission in tropical area by Tropical Rainfall Measurement Mission (TRMM) satellite. TRRM satellite can measure rainfall intensity from three hours, daily, to monthly scale.

Climate information is highly needed in disaster mitigation as a reference in policy making. Climate information advantages in agriculture are the avalaibility of ground water for plants. Based on the capability to conduct climate analysis both in macro or micro scale able to generate product that can be used to support prospective farming and highly competitive farming, e.g., through plants water balance analysis to determine the correct planting time and water surplus and deficit period in various growth phase.

Based on the explained background, the formulation of the research problem is how to utilize TRMM satellite for agroclimate zonation based on water balance analysis? The scope of problem are (1) Research study area is South Kalimantan, (2) TRMM Satellite data used is TRMM 3b43 data which is monthly rainfall estimation data with spatial resolution $0.25 \times 0.25$ degree, and (3) foeld water balance calculation based on Thornthwaite and Mather method. Field Capacity Value (KL) and Permanent Wilting Point (TLP) based on field water balance technical guide from BMKG. This research purpose is to make agroclimate zonation based on field water balance based on TRMM satellite data in South Kalimantan.

\section{METHODS OF RESEARCH}

This research is conducted in South Kalimantan Province which is located between $1^{\circ} 20^{\prime} \mathrm{S}-4^{\circ} 10^{\prime} \mathrm{S}$ and $114^{\circ} 19^{\prime} \mathrm{E}-116^{\circ} 33^{\prime} \mathrm{E}$. The research is conducted in six months from March to August 2016. For research location and rain observation post in South Kalimantan can be viewed in detail in

Graphic 1.

Research instrument consisted of computer, GrADS Open Software version 2.0, Matlab software version 7.8, Arc GIS 10.2, and Microsoft Excel for RMSE value and calculation and correlation. Material used is TRRM satellite type 3B43 in the form of grid data with monthly temporal resolution and spatial resolution $0.25^{\circ} \times 0.25^{\circ}$ with $1998-2015$ data period. Data format in the form of binary data and downloaded from $\mathrm{ftp}: / /$ disc2.nascom.nasa.gov/data/TRMM/Gridded/3B43_V7. Surface temperature data in the form of grid data from European Centre for Medium-Range Weather Forecasts (ECMWF) 1998-2015 periods in netcdf format downloaded from http://www.ecmwf.int/en/research/climate-reanalysis/browse-reanalysis-datasets.

Surface rainfall data 1998-2015 period from 13 observation spot locations sourced from South Kalimantan BMKG, i.e., (1) Muara Uya, Tabalong Regency $1.88^{\circ} \mathrm{S}$ and $115.60^{\circ} \mathrm{E},(2)$ Batu Mandi, Balangan Regency $2.45^{\circ} \mathrm{S}$ and $115.41^{\circ} \mathrm{E}$, (3) Sei Pandan, Hulu Sungai Utara $2.47^{\circ} \mathrm{S}$ and $115.18{ }^{\circ} \mathrm{E},(3)$ Hambawang Beach, Hulu Sungai Tengah Regency $2.64^{\circ} \mathrm{S}$ and $115.34^{\circ} \mathrm{E}$, (4) Simpur, Hulu Sungai Selatan $2.80^{\circ} \mathrm{S}$ and $115.23^{\circ} \mathrm{E}$, (5) Sungai Raya SMPK, Hulu Sungai Selatan Regency $2.86^{\circ} \mathrm{S}$ and $115.24^{\circ} \mathrm{E}$, (6) Banjarbaru, $3.46^{\circ} \mathrm{S}$ and $114.84^{\circ} \mathrm{E}$, (7) Simpang Empat, Banjar Regency $3.22^{\circ} \mathrm{S}$ and $115.06^{\circ} \mathrm{E}$, (8) Sei Tabuk, Banjar Regency $3.33^{\circ} \mathrm{S}$ and $114.68^{\circ} \mathrm{E}$, (9) Marabahan, Batola Regency $2.98^{\circ} \mathrm{S}$ and $114.74^{\circ} \mathrm{E}$, (10) Jorong, Tanah Laut Regency $3.96{ }^{\circ} \mathrm{S}$ and $114.92^{\circ} \mathrm{E}$, (10) Tambang Ulang, Tanah Laut Regency 
3.67 $\mathrm{S}$ and $114.71^{\circ} \mathrm{E},(11)$ Stagen Kotabaru Regency $3.30^{\circ} \mathrm{S}$ and $116.17^{\circ} \mathrm{E}$, (12) Tambang Ulang, Tanah Laut Regency $3.67^{\circ} \mathrm{S}$ and $114.71{ }^{\circ} \mathrm{E}$, and (13) Stagen Kotabaru Regency $3.30^{\circ} \mathrm{S}$ and $116.17^{\circ} \mathrm{E}$.

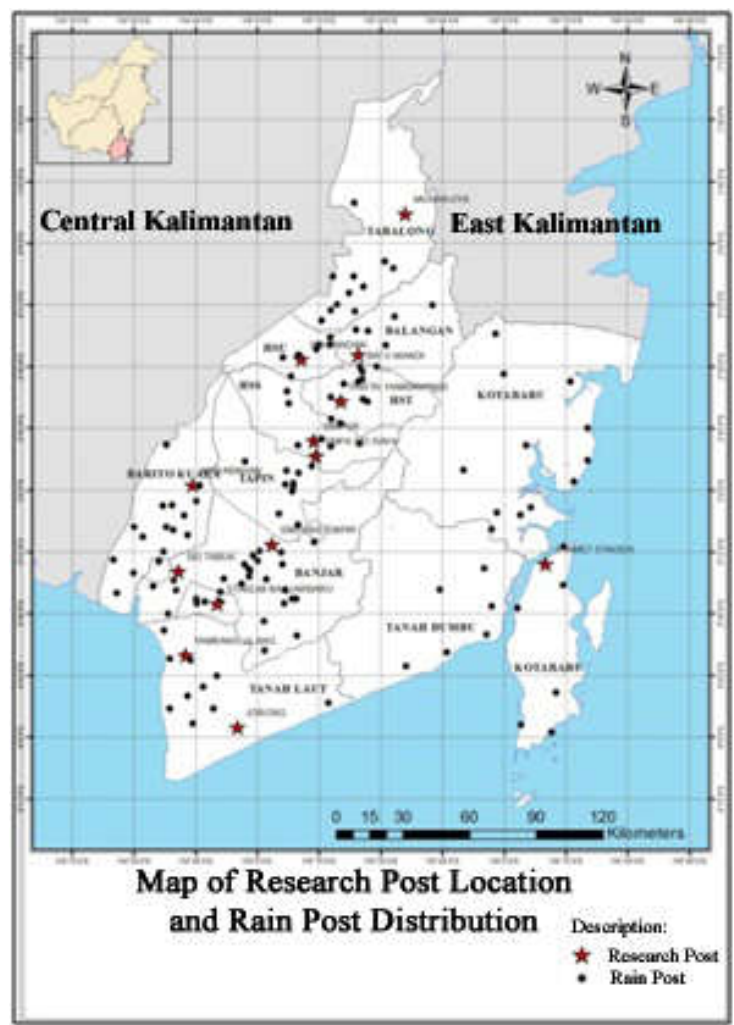

Graphic 1 - Research location and rain post in South Kalimantan

Research Procedure. The stages in this research are:

1. Determining Input Data. Main data used is monthly rain data from TRMM satellite type 3B43 $1998-2015$ data period in the form of grid with spatial $0.25^{\circ} \times 0.25^{\circ}$. Data format in the form of binary data downloaded from $\mathrm{ftp} / / /$ disc2.nascom.nasa.gov/data/TRMM/Gridded/3B43_V7. Supporting data in the form of monthly surface rainfall data $1998-2015$ period from BMKG observation spot in South Kalimantan for TRMM data validation. Monthly surface temperature data from ECMWF reanalysis data in netcdf format 1998 - 2015 periods.

2. TRMM Satellite Data Extraction. Binary format of TRMM Satellite Data extracted to certain grid (research domain area) by using GRADS software. Next data binary converted into numerical data with Matlab software. Data from conversion result compiled as monthly data serios from 1998 to 2015.

3. TRRM Satellite Rainfall Data and Surface Rainfall Data Validation. TRRM rainfall data and surface rainfall data validation applied correlation analysis ( $r$ ). Correlation coefficient calculated by using equation (Wilks, 1995):

$$
r_{\hat{r}}=\frac{\sum_{i=1}^{n}\left(Y_{i}-\bar{Y}\right)\left(\hat{Y}_{i}-\overline{\hat{Y}}\right)}{\sqrt{\sum_{i=1}^{n}\left(Y_{i}-\bar{Y}\right)^{2}} \sqrt{\sum_{i=1}^{n}\left(\hat{Y}_{i}-\overline{\hat{Y}}\right)^{2}}}
$$


Where: $r_{Y \hat{Y}}=$ correlation coefficient between TRMM satellite data with surface observation rainfall data; $Y_{i}=$ TRMM satellite data in data satelit TRMM in $i$ period with $i=1,2, \cdots, n$; $\bar{Y}=$ average TRMM satellite data values; $\hat{Y}_{i}=$ observation rainfall data in $i$ period with $i=1,2, \cdots, n ; \overline{\hat{Y}}=$ observation rainfall average value; $n=$ period length.

Water balance analysis stages are:

- ECMWF reanalysis surface temperature data extraction on set grid.

- Calculating surface temperature value in 1998 - 2015 period for every set grid.

- Calculating Potential Evapotranspiration (ETP) value by using Thornthwaite and Mater method (1957).

- Calculating ground water avalaibility with this equation:

$$
\text { Ground water avalaibility }(\mathrm{ATI})=\frac{K A T-T L P}{K L-T L P} \times 100 \%
$$

Where: KAT= ground water level; TLP = permanent wilting point; $\mathrm{KL}=$ field capacity and avalaible water.

What categorized into three parts are:

- Lack, if ground water avalaibility $<40 \%$;

- Medium, if ground water avalaibility $40 \%-60 \%$;

- Sufficient, if ground water avalaibility $>60 \%$.

A month experience rainy season rainfall ratio $(\mathrm{CH})$ and ETp of related month has value $>0.75$. Dry season happen when the ratio of Deficit $(D)$ and ETp of related month has value $>0.5$, meanwhile if the ratio is between $0-0.5$ then it is called transition season or time.

This research procedure flow is presented in

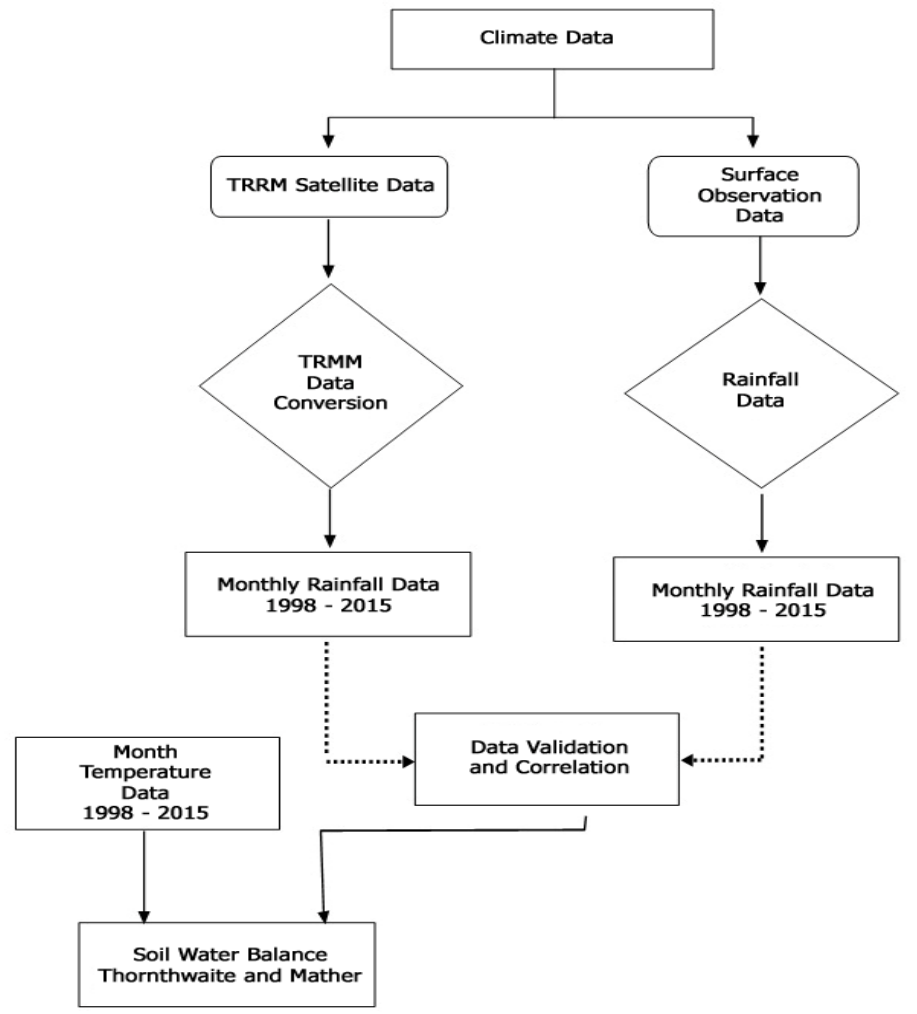

Graphic 2. 


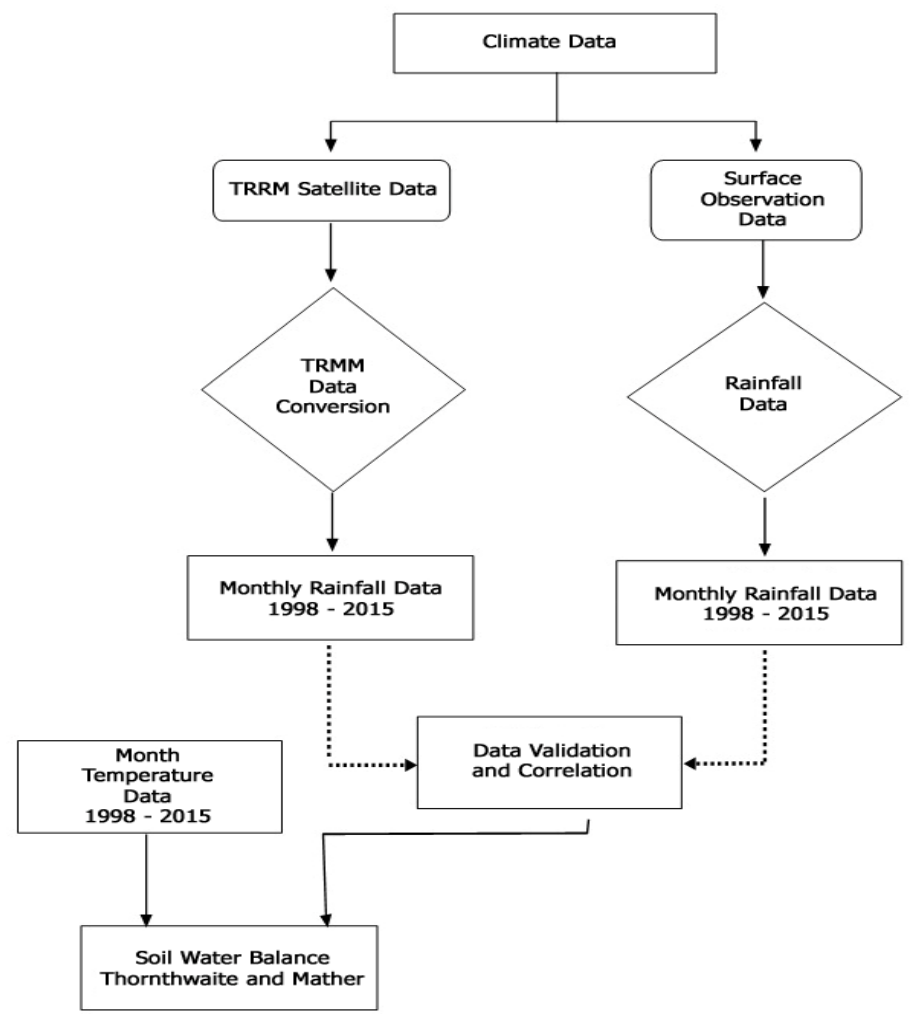

Graphic 2 - Procedure Flow Diagram

\section{RESULTS AND DISCUSSION}

TRRM Satellite Data Validation and Surface Rainfall Data. TRRM data and surface rainfall data validation in this research is conducted by taking 13 rainfall observation spots sample and the distribution of data representing all research areas. Rainfall data samples taken are adjusted with TRRM grid data. Relation level of those two data is analysed with ( $r$ ) correlation value.

Table 1 - Correlation Value and TRMM Satellite RMSE and Surface Rainfall

\begin{tabular}{llllllll}
\hline \multirow{2}{*}{ No } & Observation Spots & \multicolumn{3}{c}{ Monthly Series } & \multicolumn{3}{c}{ Monthly Average } \\
& & $\mathrm{r}_{\text {count }}$ & RMSE & $\mathrm{P}_{\text {value }}$ & $\mathrm{r}_{\text {count }}$ & RMSE & $\mathrm{P}_{\text {value }}$ \\
\hline 1 & Banjarbaru & 0.86 & 67.70 & 0.00 & 0.99 & 19.46 & 0.00 \\
2 & Muara Uya & 0.79 & 86.70 & 0.00 & 0.97 & 43.78 & 0.00 \\
3 & Sei. Pandan & 0.75 & 93.60 & 0.00 & 0.99 & 41.90 & 0.00 \\
4 & Marabahan & 0.78 & 115.20 & 0.00 & 0.99 & 0.00 & 0.00 \\
5 & Stagen & 0.80 & 86.10 & 0.00 & 0.94 & 21.35 & 0.00 \\
6 & Sei Raya SMPK & 0.79 & 77.90 & 0.00 & 0.97 & 23.17 & 0.00 \\
7 & Batu Mandi & 0.74 & 80.08 & 0.00 & 0.97 & 27.68 & 0.00 \\
8 & Hambawang Beach & 0.80 & 84.40 & 0.00 & 0.98 & 22.08 & 0.00 \\
9 & Simpur & 0.73 & 77.60 & 0.00 & 0.97 & 19.49 & 0.00 \\
10 & Simpang Empat & 0.82 & 94.20 & 0.00 & 0.97 & 26.29 & 0.00 \\
11 & Sungai Tabuk & 0.81 & 84.30 & 0.00 & 0.98 & 30.22 & 0.00 \\
12 & Tambang Ulang & 0.85 & 86.90 & 0.00 & 0.99 & 23.92 & 0.00 \\
13 & Cindai Alas Selatan & 0.80 & 100.30 & 0.00 & 0.92 & 0.00 & 0.00 \\
& Average & 0.79 & & & 0.97 & & \\
\hline
\end{tabular}


TRRM satellite monthly data and surface rainfall data series $(r)$ correlation value has good correlation between 0.73 - 0.86 with sample overall correlation average value as much as 0.78. Calcullation Result of correlation value and TRRM satellite rainfall and surface rainfall pattern comparison shows that TRMM highly capable to be used as surface rainfall data which is indicated by strong correlation value. $r$ Value in calculation result table can also be viewed in the following graphic:

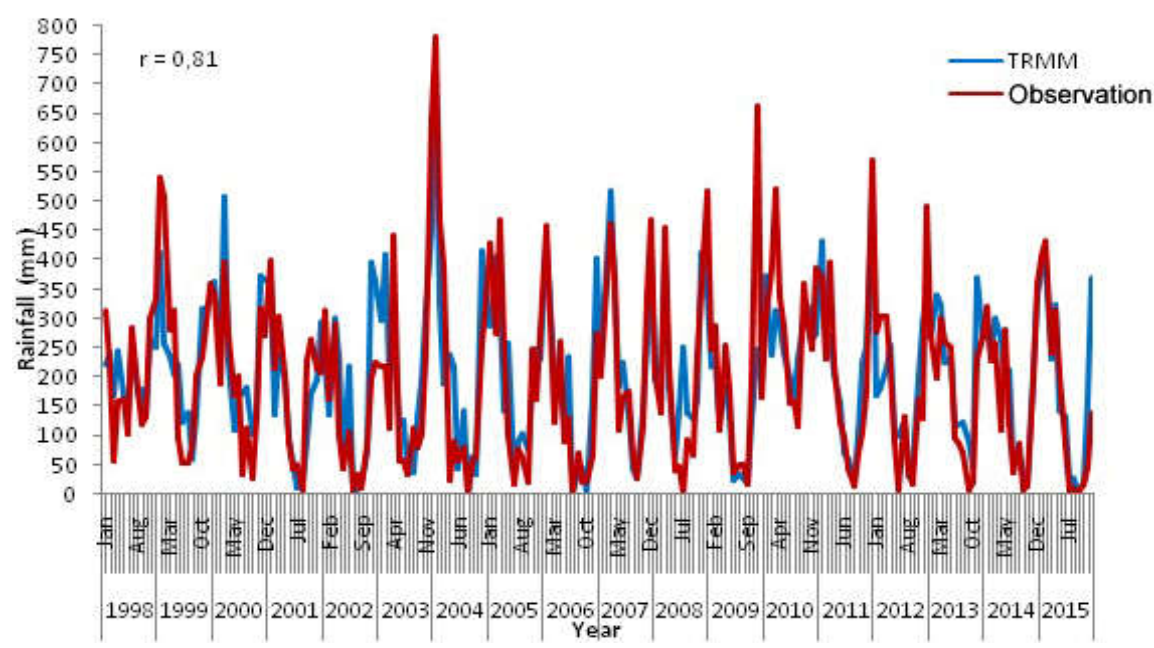

Graphic 3 - TRRM Satellite Data Series and Sei Tabuk SMPK Surface Rainfall Graphic

South Kalimantan Area Water Balance Analysis. Based on TRRM 3B43 satellite data and reanalysis temperature data on every set grid spot analysis and field water balance calculation as illustrated by Graphic 4 is conducted. The graphic shows water surplus and deficit grid spot 92 (Sei Tabuk, Banjar Regency $3.33^{\circ} \mathrm{S}$ and $114.68^{\circ} \mathrm{E}$ ). Water surplus period happen during five months, i.e., December to April, meanwhile water deficit period happen during six months, i.e., May to September.

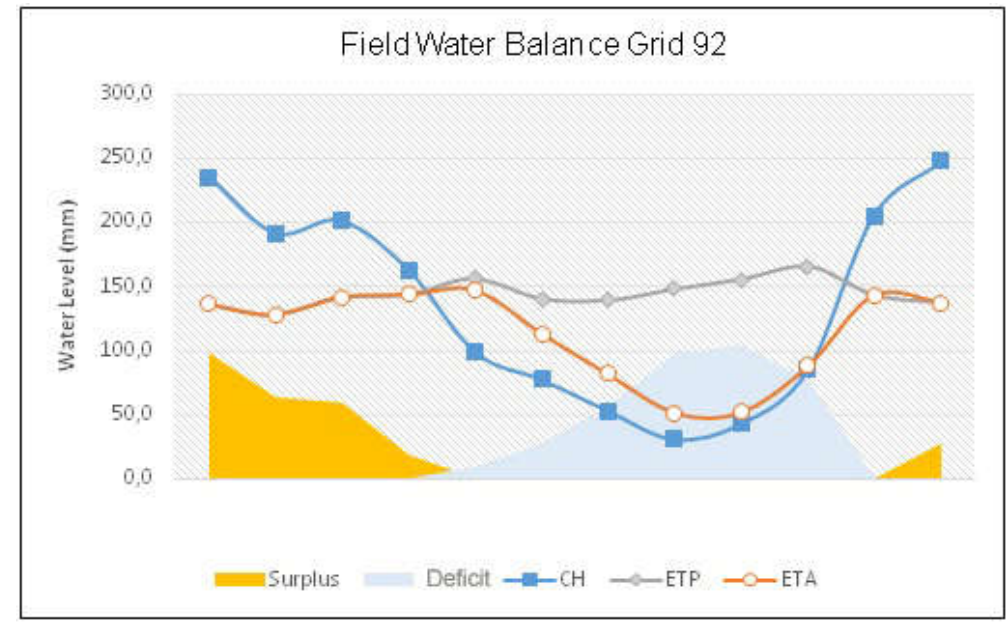

Graphic 4 - Field water balance graphic on grid 92 (Sei Tabuk, Banjar Regency $3.33^{\circ} \mathrm{S}$ and $114.68^{\circ} \mathrm{E}$ )

Since November $\mathrm{CH}>$ ETP but water surplus or deficit condition is the same with 0 (zero), this shows that rain water surplus condition is utilized to fill groundwater avalaibility through infiltration and the rest of it released in the surface. Water surplus condition happened if ground water condition has become saturated or reached field capacity. Water surplus period can be optimized for rain fed agriculture and stock water storage in the form of irrigation making or retention basin building for dry season period. In wet field, last month surplus, April started rice seedlings plantation in the field (transplanting).

Field Water Balance in December, January, and February (DJF). Ground water avalaibility level analysis in South Kalimantan in December, January, and February, shows 
general sufficient condition. The area in less and medium water availability consisted of Kotabaru regency's Laut Island. Water balance analysis in this month shows general water sufficiency except some areas of Laut Island (Kotabaru Regency) which still suffer from water deficit. Water surplus area with $50-100 \mathrm{~mm}$ value consisted of Tabalong Regency Tabalong, Balangan, Hulu Sungai Utara, Hulu Sungai Tengah, Hulu Sungai Selatan, Tapin, Northern Barito Kuala and Northern part of Banjar Regency. Water surplus with $25-50 \mathrm{~mm}$ values consisted of Tanah Laut regency, Tanah Bumbu and northern part of Kotabaru.

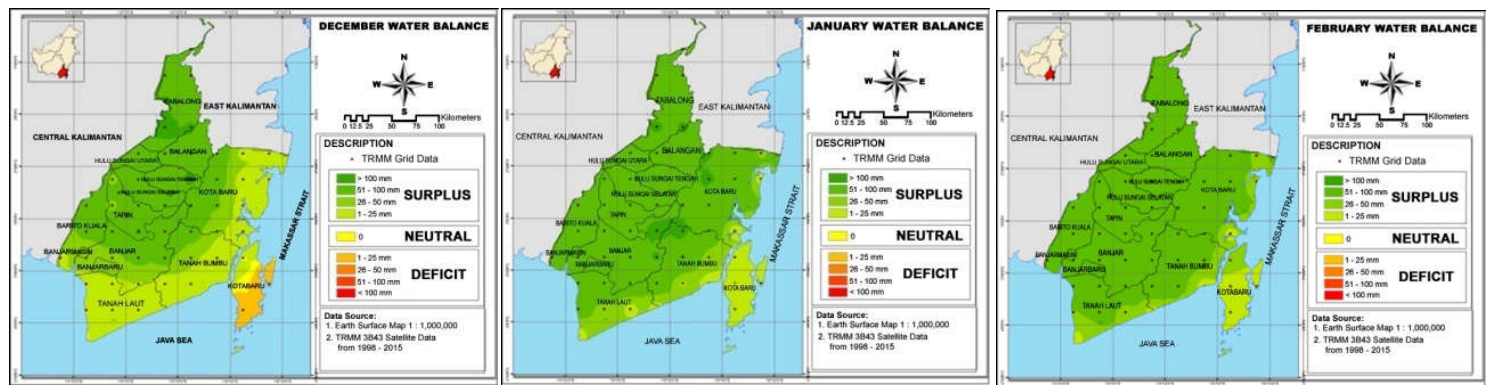

Graphic 5 - Surplus Map/December, January, and February Surplus

Ground water avalaibility level analysis in South Kalimantan in July has started to varied from less to sufficient category. Water avalaibility in less category shown with red colored legend with percentage $<40 \%$ consisted of Barito Kuala regency, Banjarmasin, western part of Banjarbaru, western part of Banjar Regency, western part of Tapin Regency, nad western part of Hulu Sungai Selatan. The variety of ground water avalaibility in July shown from "less" category to highly varied from West to East. Areas with sufficient ground water consisted of Tabalong regency, Tanah Bumbu, Kotabaru, some parts of eastern part of Tanah Laut and some parts of eastern side of Banjar.

Field water balance analysis in June, July, and August (JJA). Water deficit has extended to almost to entire areas of South Kalimantan with values around $1-25 \mathrm{~mm}$. Water deficit is around $50-100 \mathrm{~mm}$ comprised of southern part of Barito Kuala and Banjarmasin. Water deficit with values of $20-50 \mathrm{~mm}$ comprised of Hulu Sungai Utara, western part of Hulu Sungai Selatan, western part of Tapin, western part of Banjar regency, western part of Tanah Laut coast, Banjarbaru and Barito Kuala. Groundwater avalaibility and water balance volume is varied from west to east.
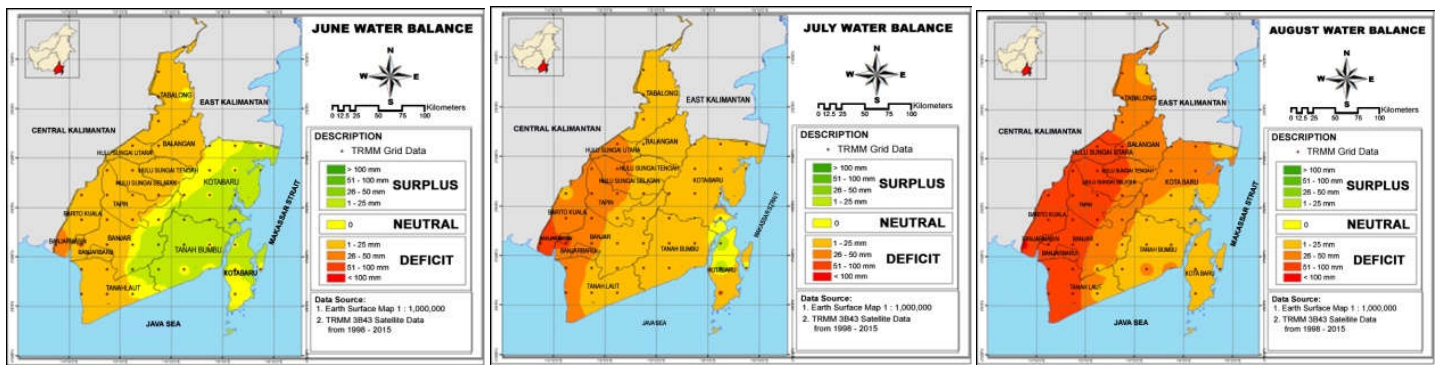

Graphic 6 - Surplus/ Defisit Map in June, July, and August

Based on South Kalimantan area water balance spatial analysis the groundwater avalaibility period is in sufficient category $(>60 \%)$ berkisar $5-9$ bulan, meanwhile water surplus period is around $4-7$ months. In detail, ground water avalaibility level period is in sufficient period and water surplus period in South Kalimantan in tabulation for each regency shown in Table 2.

Table 2 - South Kalimantan area field water balance analysis

\begin{tabular}{|c|c|c|c|c|c|c|}
\hline No & Regency / City & $\begin{array}{c}\text { Water Avalaibility } \\
(>60 \%)\end{array}$ & $\begin{array}{c}\text { Water } \\
\text { Surplus }\end{array}$ & $\begin{array}{c}\text { Rainy Season } \\
\text { Period (CH/ETP) }\end{array}$ & $\begin{array}{c}\text { Dry Season } \\
\text { Period (D/ETP) }\end{array}$ & $\begin{array}{c}\text { Transition Period } \\
(\mathrm{D} / \mathrm{ETP})<0.5\end{array}$ \\
\hline 1. & Tabalong Regency & $8-9$ months & 6 months & Nov-Jun & 0 & 0 \\
\hline
\end{tabular}




\begin{tabular}{|c|c|c|c|c|c|c|}
\hline 2. & Balangan Regency & $8-9$ months & $\begin{array}{l}5-6 \\
\text { months }\end{array}$ & Nov-May & 0 & May-Oct \\
\hline 3. & $\begin{array}{c}\text { Hulu Sungai Utara } \\
\text { Regency }\end{array}$ & 8 months & 5 months & Oct-Jun & Sep & May-Agt and Oct \\
\hline 4. & $\begin{array}{c}\text { Hulu Sungai Tengah } \\
\text { Regency }\end{array}$ & $8-9$ months & 5 months & Nov-Jun & 0 & May-Oct \\
\hline 5. & $\begin{array}{c}\text { Hulu Sungai Selatan } \\
\text { Regency }\end{array}$ & $7-8$ months & 5 months & Nov-May & Agt-Sep & May-Jul and Oct \\
\hline 6. & Tapin Regency & $7-8$ months & $\begin{array}{c}5-6 \\
\text { months }\end{array}$ & Nov-Apr & Sep & May-Jul and Oct \\
\hline 7. & Banjar Regency & $7-9$ months & $\begin{array}{c}5-7 \\
\text { months }\end{array}$ & Nov-Apr & Agt-Sep & May-Jul and Oct \\
\hline 8. & $\begin{array}{c}\text { Tanah Laut } \\
\text { Regency }\end{array}$ & $7-8$ months & 5 months & Nov-Apr & Agt-Sep & May-Jul and Oct \\
\hline 9. & $\begin{array}{c}\text { Tanah Bumbu } \\
\text { Regency }\end{array}$ & $7-8$ months & $\begin{array}{l}5-7 \\
\text { months }\end{array}$ & Nov-Jul & 0 & Jun-Oct \\
\hline 10. & Kota Baru Regency & $6-7$ months & $\begin{array}{c}5-7 \\
\text { months }\end{array}$ & Nov-Jul & 0 & Agt-Oct \\
\hline 11. & $\begin{array}{l}\text { Barito Kuala } \\
\text { Regency }\end{array}$ & 6 months & 5 months & Nov-Apr & Agt-Sep & May-Jul and Oct \\
\hline 12. & Banjarbaru City & $5-7$ months & 5 months & Nov-May & Agt-Sep & May-Jul and Okt \\
\hline 13. & Banjarmasin City & 6 months & 5 months & Nov-Apr & Agt-Sep & May-Jul and Oct \\
\hline
\end{tabular}

Water balance analysis above is early information that can be used as advice in agricultural activity planning in South Kalimantan. Generally ground water avalaibility period with sufficient category happen in November - May, meanwhile water surplus period also happen during November - May period. Water balance analysis result in South Kalimantan also gives early information on the potential of drought or drought-prone areas. From water balance analysis, the level of ground water avalaibility is in less category $(<40 \%)$ and water deficit happen during August to September (two months).

Period information of drought-prone area can be suggestion to anticipate and solve drought disaster. South Kalimantan almost every year in dry season suffers from smoke disaster due to field fire. Climate resource utilization has important role as one of useful information in planning and managing natural resources and as basic reference in policy planning and policy making.

Local agribusiness that sensitive to photo periodism in South Kalimantan generally started on October, both direct planning in dry field or stages planning in wet field as explained as following:

\begin{tabular}{|c|c|c|c|c|c|c|c|c|c|c|c|c|}
\hline \multirow{2}{*}{ Activity } & \multicolumn{12}{|c|}{ Month } \\
\hline & 10 & 11 & 12 & 1 & 2 & 3 & 4 & 5 & 6 & 7 & 8 & 9 \\
\hline $1^{\text {st }}$ Seedling (dry field) & \multicolumn{2}{|c|}{ SW } & & & & & & & & & & \\
\hline $2^{\text {nd }}$ Seedling (wet field) & & \multicolumn{2}{|c|}{ TP1 } & & & & & & & & & \\
\hline $3^{\text {rd }}$ Seedling (wet field) & & & \multicolumn{4}{|c|}{ TP2 } & & & & & \multirow{2}{*}{\multicolumn{2}{|c|}{ Panen }} \\
\hline Main Rice (wet field) & & & & & & & & & 53 & & & \\
\hline
\end{tabular}

Source: Hasegawa et al (2004).

Based on Table 2, month amounts to conduct planting pattern business above still possible, but based on Graphic 6 there is a shift in rainy season that previously in April shifted to May. That time shift affected to result reduction because vegetative time around one month in April (above graphic). Meanwhile, local rice planted is photo-periodism sensitive which affected to flowering in June. This will reduce the time for carbohydrate accumulation which left around one month (May). Rainy season end time shift become more regressed, and this is almost spread evenly in South Kalimantan Monsoon area. This is need to be anticipated, one of it is by looking for short time varieties, therefore after the transplanted rice has enough time for active vegetative and seedlings. Some varieties with shorter age from the elders have been assembled like what have been done by Wahdah, Rusmayadi and Zulhidiani (2016) towards photo-periodism sensitive local variety Siam Unus mutant M6 with 111 - 115 days age after transplanting. 


\section{CONCLUSION}

Field water balance analysis mapping based on TRMM satellite data shows ground water avalaibility with sufficient category happen during November - July period, meanwhile water surplus period happen during December - June period. Water balance analysis gave more detail information to determine agriculture planting pattern. Water balance analysis gave information on planting potential time avalaible and gave information on drought-prone areas which is very useful to be used for the basis of planting planning and management.

\section{REFERENCES}

1. Hasegawa, T. 2004. Grain yield and its variation of local rice varieties grown on acid sulfate soil in South Kalimantan.Jpn. J.Crop Sci.73 (1), 220-221.

2. Oldeman, R.L. 1980. The agro-climatic maps of Kalimantan, Maluku, Irian Jaya, and Bali West and East Nusa Tenggara Contrib. Centr. Res. Inst.Agrc. Bogor.

3. Raihani Wahdah. 2016. Performing of agronomic characters of M6 of local rice mutant lines of South Kalimantan.International Journal of Biosciences, 9(6): 114-124.

4. Rusmayadi, G. 2012. Pertanian Dalam Bayang-Bayang Iklim Ekstrim. P3AI Universitas Lambung Mangkurat Banjarmasin.

5. Syaifullah, M.D. 2011.Validasi Data TRMM Terhadap Data Curah Hujan Aktual di Tiga DAS di Indonesia. Jurnal Meteorologi and Geofisika.15: 109-118.

6. Simpson, J. (Edt.), 1998, Report ofthe Science Steering Group for a Tropical Rainfall Measuring Mission (TRMM), GSFC (Goddard Space Flight Center).

7. Thornthwaitre. 1957. Instruction and tables for computing potential evapotraspiration and the water balance. Drexel Instute of technology.Laboratory of Climatology. USA.

8. Wilks, D.S. 1995. Statistical Methods in the Atmospheric Sciences.Academic Press Inc. 